\title{
ANALISIS POTENSI WILAYAH PENGEMBANGAN TERNAK RUMINANSIA DI KABUPATEN LAMONGAN
}

\author{
Ratna Kumala Dewi S.Pt, MMG, M.Eng \\ Program Studi Peternakan Fakultas Peternakan Universitas Islam Lamongan \\ Jl.Veteran No.53.A Lamongan \\ e-mail: ratnakd@gmail.com
}

\begin{abstract}
ABSTRAK
Kabupaten Lamongan memiliki potensi yang cukup besar di dalam mengembangkan sektor peternakannya. Fenomena ini terlihat dari kontribusi sektor terhadap pembentukan PDRB pertanian dan wilayah yang selalu meningkat antar waktu. Tujuan utama dari penelitian ini adalah (1) menentukan komoditas ternak ruminansia yang dapat diunggulkan berdasarkan dukungan sumberdaya wilayah yang dimiliki oleh Kabupaten Lamongan; dan (2) mengidentifikasi wilayah mikro yang dapat dijadikan sebagai basis pengembangan peternakan. Penelitian dilakukan pada tanggal 12 sampai dengan 30 Oktober 2018 di wilayah administratif Kabupaten Lamongan. Metode penelitian yang digunakan dalam penelitian ini adalah analitis statistik dan deskriptif dengan data sekunder yang dihimpun merupakan data berkala selama periode tujuh tahun yaitu dari tahun 2010 sampai dengan tahun 2017 yang bersumber dari beberapa instansi terkait. Variabel yang diamati di dalam penelitian ini meliputi variabel populasi ternak, Lahan pertanian, Rumahtangga pertanian, Fasilitas pelayanan peternakan dan Variabel pendukung. Model perhitungan dalan penelitian ini meliputi: (a) Analisis LQ (Location Quotient), (b) pendugaan ketersediaan sumber pakan, (c) perhitungan daya tampung wilayah, (d) indeks spesialisasi Rumah Tangga Pertanian. Berdasarkan seluruh analisis yang dilakukan terhadap ketersediaan sumberdaya dan keterbatasan yang dimiliki oleh Kabupaten Lamongan maka wilayah pengembangan ternak ruminansia dapat diarahkan kepada beberapa wilayah dan beberapa subsistem; subsistem budidaya dan pasca panen (pengolahan). Wilayah pengembangan ternak meliputi Kecamatan Mantup, Tikung, Ngimbang, Sambeng, Modo, Solokuro dan Paciran sebagai sentra pengembangan subsistem budidaya, sementara Sukorame, Deket dan Babat sebagai wilayah ekspansinya. Sementara subsistem pengolahan dapat diarahkan terutama kepada Turi dan Paciran. Meskipun kedua wilayah ini tidak direncanakan untuk menjadi wilayah pengembangan sektor pertanian, tetapi subsistem pengolahan produk ternak tentunya masih dapat dilakukan. Upaya ini dapat dijustifikasi karena subsistem pengolahan tidak membutuhkan lahan sebagai basis produksinya, melainkan keterkaitan antar wilayah.
\end{abstract}

Kata Kunci: potensi, pengembangan wilayah, zonasi, ternak ruminansia

\section{PENDAHULUAN}

Kabupaten Lamongan memiliki potensi yang cukup besar di dalam mengembangkan sektor peternakannya. Fenomena ini terlihat dari kontribusi sektor terhadap pembentukan PDRB pertanian dan wilayah yang selalu meningkat antar waktu. Laju pertumbuhan PDRB sektor peternakan Lamongan antara tahun 2012 sampai dengan tahun 2015 tercatat sebesar 4,25 persen; relatif cukup tinggi dibandingkan dengan rata-rata wilayah lainnya di dalam lingkup Jawa Timur yang mencapai hanya 3 persen per tahun. Cukup tingginya laju pertumbuhan kontribusi tersebut tentunya merupakan indikasi dari juga tingginya laju pertumbuhan populasi ternak yang berada di kabupaten Lamongan. Pada tahun terakhir pengamatan, laju pertumbuhan populasi ternak ruminansia mencapai hampir 8 persen per tahun. Sementara ternak non ruminansia dan unggas secara bersama-sama membentuk laju pertumbuhan sebesar hampir 11 persen per tahun. Fenomena pertumbuhan ini tentunya menunjukkan Lamongan masih memiliki keunggulan komparatif pada sisi produksi untuk berbagai komoditas ternak komersial. Keunggulan ini juga yang menunjukkan bahwa iklim yang kondusif (enabling environment) diperkirakan menjadi 
salah satu sumber pertumbuhan ekonomi di sektor peternakan tersebut.

Sebagaimana strategi pembangunan wilayah Jawa Timur yang bias sektoral, pembangunan wilayah Kabupaten Lamongan - yang tercantum di dalam Rencana Tata Ruang Wilayah (RTRW) - diarahkan kepada pengembangan wilayah yang berbasis industri. Pada satu sisi, pengembangan wilayah industrial akan memberikan peluang kepada sektor peternakan untuk dapat melakukan ekspansi pasar, namun pada sisi lain - ketika mekanisme pasar yang terjadi cenderung asimetris - pengembangan industri dalam jangka panjang justru akan mereduksi struktur insentif yang tercipta di dalam sektor peternakan tersebut. Zoning atau pewilayahan - khususnya untuk sistem produksi ternak diyakini merupakan salah satu upaya untuk mengantisipasi konflik pemanfaatan sumberdaya secara sektoral. Selain beberapa keunggulan yang dapat tercipta dari aglomerasi wilayah (Porter, 1998), pewilayahan peternakan - atau pertanian secara umum - dapat menjamin ketermampuberlanjutan sektor peternakan di tengah perubahan ekonomi yang terjadi. Kabupaten Lamongan meliputi beberapa wilayah memiliki potensi untuk menjadi wilayah pengembangan peternakan di Jawa Timur, baik di dalam aspek agroklimat maupun keragaan sosial ekonomi masyarakatnya. Di dalam konteks ini, salah satu upaya yang dapat dilakukan untuk memfasilitasi perkembangan peternakan yang berkelanjutan dengan melakukan suatu identifikasi potensi wilayah yang didasarkan pada ukuran-ukuran sumberdaya yang digunakan oleh sektor peternakan. Oleh karena itu, tujuan utama dari penelitian ini adalah (1) menentukan komoditas ternak ruminansia yang dapat diunggulkan berdasarkan dukungan sumberdaya wilayah yang dimiliki oleh Kabupaten Lamongan; dan (2) mengidentifikasi wilayah mikro yang dapat dijadikan sebagai basis pengembangan peternakan.

Salah satu upaya pengembangan dan pembangunan sektor peternakan di Kabupaten Lamongan dapat dilakukan dengan cara memanfaatkan seluruh sumberdaya yang dimiliki. Adapun sumberdaya yang tersedia dan dapat dimanfaatkan mencakup sumberdaya alam, manusia dan (modal). Keberadaan populasi ternak di suatu wilayah diyakini merupakan resultan dari interaksi beberapa dimensi yang terdapat di dalam wilayah tersebut. Beberapa dimensi tersebut mencakup teknologi (moda produksi), ekonomi dan kondisi sosial masyarakat. Ketiga dimensi ini berinteraksi membentuk suatu lingkungan kondusif (enabling environment) yang memungkinkan populasi ternak dapat berkembang (Steinfeld et al., 1997). Maka dengan itu, optimasi pengelolaan beragam sumberdaya yang tersedia untuk menjamin keberlanjutan lingkungan tersebut merupakan langkah awal yang dapat diambil dalam usaha pengembangan sub sektor peternakan di wilayah Kabupaten Lamongan.

Sumberdaya alam tetap menjadi basis utama berlangsungnya kegiatan usahaternak, terutama untuk ternak ruminansia. Sebagai penyedia pakan, keterkaitan antara wilayah produksi tanaman pangan dan produksi ternak menjadi sebuah esensi di dalam proses pengembangan peternakan. Data-data publikasi (BPS, 2006) menunjukkan bahwa secara spasial populasi ternak ruminansia menyebar mengikuti wilayah produksi tanaman pangan berlahan sempit di berbagai wilayah di Indonesia. Fenomena tersebut menunjukkan bahwa wilayah pertanian tanaman pangan memberikan kontribusi yang cukup signifikan terhadap terciptanya lingkungan yang kondusif bagi sektor peternakan, terutama di dalam konteks penyediaan sumber pakan.

Pola spasial penyebaran dan konsentrasi populasi ternak tersebut memberikan setidaknya dua indikasi. Pertama, pemeliharaan ternak tampaknya terkonsentrasi pada rumahtangga pertanian berlahan sempit. Indikasi ini menunjukkan bahwa kunci pengembangan peternakan - terutama di dalam konteks peningkatan populasi - berada pada rumahtangga tersebut. Hal ini juga dapat menjustifikasi usaha ternak yang faktanya memang merupakan kegiatan komplementer dari usaha tani sebagai residu dari sumberdaya yang digunakan (Upton, 2004). Indikasi ke dua, dengan semakin cepatnya laju konversi lahan pertanian - terutama di pulau Jawa - peluang pengembangan peternakan tentunya akan semakin kecil jika tidak terdapat upaya-upaya untuk mengantisipasi dinamika tersebut.

Pada masa depan, Davendra (2002) menyatakan bahwa keberlanjutan peternakan akan sangat bergantung pada terbentuknya "area wide integration". Konsep ini, selain dari keterpaduan antara produksi ternak dan tanaman pangan, juga merujuk pada integrasi wilayah antara sektor pertanian secara umum dengan sektor non pertanian (industri dan jasa). Berdasarkan temuan empiris, Ellis dan Schumberg (1998) dapat menyatakan bahwa di dalam jangka panjang setiap kegiatan produksi yang membutuhkan lahan sebagai 
sumberdaya utamanya (seperti pada produksi ternak) akan berada di dalam lingkaran wilayah urban. Kondisi ini diperkuat dengan temuan Drescher et al (2000) yang menunjukkan bahwa di dalam tataran perencanaan wilayah, kegiatan pertanian di wilayah urban menjadi salah satu komponen utama dalam perencanaan.

Di dalam konteks pengembangan peternakan di Kabupaten Lamongan, beberapa temuan empiris tersebut tentunya dapat menjustifikasi pentingnya wilayah spesifik yang diperuntukkan bagi pengembangan kegiatan-kegiatan peternakan. Secara historis, wilayah Lamongan merupakan jangkar dari lalu-lintas perdagangan ternak antar propinsi yang ditandai dengan terdapatnya pasar hewan yang cukup besar dalam lingkup Jawa Timur, yaitu Pasar Hewan Babat. Berkaitan dengan kondisi tersebut, identifikasi wilayah yang memiliki potensi untuk menjadi basis pengembangan ternak tampaknya menjadi salah satu komponen di dalam perencanaan secara keseluruhan. Berdasarkan kerangka konsep sebelumnya, maka terminologi potensi wilayah pengembangan peternakan akan merujuk kepada indikator ketersediaan lahan pertanian, spesialisasi rumahtangga pertanian dan ketersediaan infrastruktur yang berkaitan dengan sektor peternakan.

\section{MATERI DAN METODE}

Penelitian dilakukan pada tanggal 12 sampai dengan 30 Oktober 2018 di wilayah administratif Kabupaten Lamongan. Metode penelitian yang digunakan dalam penelitian ini adalah analisis statistik dan deskriptif.

Data utama yang digunakan dalam penelitian ini adalah data sekunder. Data sekunder yang dihimpun merupakan data berkala selama periode tujuh tahun yaitu dari tahun 2010 sampai dengan tahun 2017 yang bersumber dari beberapa instansi terkait antara lain yaitu Dinas Peternakan Propinsi Jawa Timur, Dinas Peternakan dan Kesehatan Hewan Kabupaten Lamongan, Badan Pusat Statistik Propinsi Jawa Timur, Badan Pusat Statistik Kabupaten Lamongan, BAPEDA Kabupaten Lamongan dan Dinas Pertanian Tanaman Pangan Kabupaten Lamongan.

Variabel yang diamati di dalam penelitian ini meliputi variabel (1) populasi ternak yang merupakan jumlah ternak yang terdapat di suatu wilayah (kecamatan) dengan menggunakan unit perhitungan Satuan Ternak (ST). Populasi ternak terdiri dari sembilan jenis ternak yaitu ternak ruminansia besar (sapi perah, sapi potong dan kerbau) dan ternak ruminansia kecil (domba dan kambing). (2) Lahan pertanian sebagai proksi ketersediaan sumber pakan ternak (hektar per tahun); mencakup jagung, padi, kacang tanah, kacang kedele, ketela rambat, ketela pohon, pucuk tebu. (3) Rumah tangga pertanian yang memiliki lahan (unit). (4) Fasilitas pelayanan peternakan yang merupakan satuan unit usaha yang menyediakan dan memberikan pelayanan, baik berupa jasa maupun barangbarang kebutuhan pokok usaha peternakan (SAPRONAK); meliputi unit pembibitan ternak, Pos Kesehatan Hewan, Pos Inseminasi Buatan beserta inseminatornya, Petugas Penyuluh Lapangan dan Rumah Potong Hewan serta Rumah Potong Ayam. (5) Variabel pendukung yang meliputi Rencana Tata Ruang Wilayah (RTRW) Pemerintah Daerah dan Rencana Strategis Pembangunan Daerah Kabupaten Lamongan.

Model perhitungan yang digunakan dalam penelitian ini:

1. Location Quotient (LQ)

Model ini digunakan untuk membandingkan kegiatan basis di dalam suatu wilayah secara relatif terhadap wilayah yang lebih besar secara hirarkikal. Secara matematis persamaan LQ dapat dituliskan sebagai berikut (Dinc, 2002):

$$
L Q=\frac{X_{i j} / \sum_{i=1}^{5} X_{i j}}{\sum_{i=1}^{27} X_{i j} / \sum_{j=1}^{27} 5 X_{i j}}
$$

Keterangan :

Xij Populasi ternak jenis ke-i dalam $\mathrm{i}=1$ satuan ternak ruminansia (ST) di Kecamatan ke-j.

$5 \mathrm{Xij}$
$\mathrm{C}$ $\mathrm{n}=27 \quad$ ternak) di Kecamatan ke-j (ST)

$\sum$ Xij Populasi jenis ternak ke-i (ST) di $i=1$ seluruh kecamatan atau di wilayah $\mathrm{n}=17 \quad 5$ kabupaten yang bersangkutan

$\sum \quad \sum$ Xij Total populasi ternak (dari 5 jenis $\mathrm{j}=1 \quad \mathrm{i}=1$ ternak) dalam ST di seluruh wil. Kecamatan

Apabila diperoleh LQ untuk jenis ternak tertentu di kecamatan ke-j lebih besar dari sama dengan satu $(L Q \geq 1)$, berarti kecamatan tersebut merupakan daerah basis bagi komoditas tersebut, sebaliknya jika LQ 
lebih kecil dari satu $(\mathrm{LQ}<1)$ berarti bukan daerah basis.

\section{Pendugaan Ketersediaan Sumber Pakan}

Kesesuaian lokasi dilakukan dengan melihat kapasitas tampung dari wilayah, yang didasarkan pada ketersediaan hijauan makanan ternak untuk ternak ruminansia. Potensi pakan yang dihitung terdiri dari ketersediaan rumput dan jerami (limbah pertanian pangan) pada luasan lahan yang ada di setiap kecamatan selama satu tahun (hektar per tahun). Lahan yang diperhitungkan adalah : (1) Lahan sawah, terdiri atas sawah irigasi teknis, setengah teknis, sederhana dan tadah hujan, (2) Lahan kering (darat), terdiri dari lahan pekarangan, tegalan dan perkebunan, ladang atau huma, pengangonan dan sebagainya dan (3) Lahan hutan, terdiri dari lahan hutan rakyat dan hutan negara. Estimasi potensi produksi bahan kering di dalam suatu wilayah dihitung berdasarkan :

- Lahan sawah $(0,77591$ x luas lahan x 0,06 $x 6,083)$ ton BK/tahun

- Lahan kering $(1,062 \mathrm{x}$ luas lahan $x$ 0,0979 x $6,083)$ ton BK/tahun

- Lahan hutan $(2,308$ x luas lahan x 0,5875 x $6,083)$ ton BK/tahun

- Limbah pertanian Luas panen (ha/th) $x$ Prod. Bahan Kering (ton/ha) $\mathrm{x}$ Indeks termanfaatkan (\%)

3. Perhitungan Daya Tampung Wilayah

4. Indeks Spesialisasi Rumah Tangga Pertanian

Menurut Dinc (2002), indeks ini digunakan untuk menggambarkan pembagian kecamatan berdasarkan aktivitas rumahtangga. Persamaan indeks spesialisasi rumahtangga pertanian dapat dituliskan dengan persamaan berikut ini:

$$
S I i=1 / 2 \sum_{i=1}^{n}\left|X_{i j} x \underline{X i}\right|^{X} x
$$

Keterangan :

Sli Indeks spesialisasi kecamatan ke-i

Xij Jumlah rumah tangga pada sektor ke-j (sektor pertanian) di kecamatan ke-i

$\mathrm{Xi}$ Jumlah rumah tangga pada semua sektor di kecamatan ke-i

$\mathrm{Xj}$ Jumlah rumah tangga di sektor ke-j (sektor pertanian) pada semua kecamatn

$X \quad$ Jumlah rumah tangga di semua sektor dan pada semua kecamatan

Untuk menginterpretasikan hasil analisis ini, digunakan kriteria sebagai berikut, jika nilainya mendekati nol berarti tidak mempunyai kekhasan (spesialisasi). Artinya kecamatan

yang di amati tidak memiliki sektor yang khas yang relatif menonjol pada perkembangannya dibandingkan dengan kecamatan lain. Jika nilainya mendekati 1 berarti terdapat kekhasan (spesialisasi). Artinya kecamatan yang diamati memiliki aktivitas yang khas yang perkembangannya relatif menonjol dibandingkan dengan kecamatan lain.

\section{HASIL DAN PEMBAHASAN \\ Komoditas Ruminansia Unggulan Kabupaten Lamongan \\ Komoditas ruminansia unggulan} ditentukan berdasarkan perkembangan populasi yang berada di Kabupaten Lamongan. Meskipun terdapat cukup banyak kriteria di dalam menentukan ternak yang memiliki potensi untuk dijadikan unggulan suatu wilayah, keragaan populasi diyakini dapat menjadi indikator utama yang dapat memberikan gambaran prinsipal mengenai keunggulan komparatif suatu wilayah dalam mempertahankan tingkat populasi ternak yang bersangkutan. Seperti yang telah dipaparkan sebelumnya, keberadaan populasi di suatu wilayah merupakan hasil interaksi antara berbagai faktor-faktor pendukung pertumbuhan, sehingga selama tidak terdapat kecenderungan yang menurun pada populasi maka diyakini enabling environment masih bekerja secara efektif. Keragaan populasi ruminansia - dalam terminologi indeks LQ disajikan berikut ini.

Tabel 1. Analisis LQ Ternak Ruminansia di Kabupaten Lamongan

\begin{tabular}{clccccc}
\hline No & \multicolumn{1}{c}{ Kec. } & $\begin{array}{c}\text { S.Poto } \\
\text { ng }\end{array}$ & $\begin{array}{c}\text { S.Per } \\
\text { ah }\end{array}$ & $\begin{array}{c}\text { Kerba } \\
\text { u }\end{array}$ & $\begin{array}{c}\text { Kambi } \\
\text { ng }\end{array}$ & $\begin{array}{c}\text { Dom } \\
\text { ba }\end{array}$ \\
\hline 1 & Sukorame & $\mathbf{1 , 2 6}$ & 0,00 & $\mathbf{5 , 0 7}$ & $\mathbf{1 , 0 2}$ & 0,62 \\
2 & Bluluk & $\mathbf{1 , 6 8}$ & 0,00 & $\mathbf{2 , 7 9}$ & 0,52 & 0,74 \\
3 & Ngimbang & $\mathbf{1 , 2 7}$ & 0,00 & $\mathbf{1 , 3 1}$ & $\mathbf{1 , 0 7}$ & 0,57 \\
4 & Sambeng & $\mathbf{1 , 6 2}$ & 0,00 & 0,00 & 0,68 & 0,63 \\
5 & Mantup & $\mathbf{1 , 3 9}$ & 0,00 & 0,00 & $\mathbf{1 , 0 7}$ & 0,43 \\
6 & Kb.bahu & $\mathbf{1 , 3 4}$ & 0,73 & 0,00 & $\mathbf{1 , 0 3}$ & 0,54 \\
7 & Sugio & $\mathbf{1 , 4 4}$ & 0,00 & 0,00 & 0,51 & $\mathbf{1 , 0 5}$ \\
8 & Kd.pring & $\mathbf{1 , 5 7}$ & 0,00 & 0,00 & 0,51 & 0,89 \\
9 & Modo & $\mathbf{1 , 6 1}$ & 0,00 & $\mathbf{1 , 4 0}$ & 0,74 & 0,55 \\
10 & Babat & 0,65 & $\mathbf{2 , 5 1}$ & 0,00 & $\mathbf{1 , 5 1}$ & 0,79 \\
11 & Pucuk & 0,15 & 0,00 & 0,00 & $\mathbf{1 , 2 6}$ & $\mathbf{1 , 7 6}$ \\
12 & Sukodadi & 0,61 & $\mathbf{2 , 8 0}$ & 0,00 & $\mathbf{1 , 1 9}$ & $\mathbf{1 , 2 6}$ \\
13 & Lamongan & 0,31 & $\mathbf{1 6 , 7 0}$ & 0,00 & $\mathbf{1 , 0 6}$ & $\mathbf{1 , 8 0}$ \\
14 & Tikung & $\mathbf{1 , 5 7}$ & 0,00 & 0,00 & 0,86 & 0,46 \\
15 & Sarirejo & 0,51 & 0,00 & 0,00 & $\mathbf{1 , 3 6}$ & $\mathbf{1 , 1 7}$ \\
16 & Deket & 0,11 & 0,00 & $\mathbf{7 , 9 8}$ & $\mathbf{1 , 5 0}$ & $\mathbf{1 , 4 7}$ \\
17 & Glagah & 0,04 & 0,00 & $\mathbf{9 , 1 7}$ & $\mathbf{1 , 0 7}$ & $\mathbf{2 , 0 9}$ \\
18 & Krb.nangun & 0,46 & 0,00 & $\mathbf{1 4 , 1 0}$ & $\mathbf{1 , 3 3}$ & $\mathbf{1 , 2 2}$ \\
19 & Turi & 0,23 & 0,00 & $\mathbf{3 , 0 0}$ & $\mathbf{1 , 7 6}$ & $\mathbf{1 , 0 2}$ \\
20 & Kalitengah & 0,62 & 0,00 & $\mathbf{3 , 8 9}$ & $\mathbf{1 , 1 9}$ & $\mathbf{1 , 2 4}$ \\
21 & Kr.geneng & 0,66 & 0,00 & 0,00 & $\mathbf{1 , 3 0}$ & $\mathbf{1 , 0 6}$ \\
22 & Sekaran & 0,27 & 0,00 & 0,00 & 0,98 & $\mathbf{1 , 9 6}$ \\
23 & Maduran & 0,20 & 0,00 & 0,00 & $\mathbf{1 , 0 9}$ & $\mathbf{1 , 9 0}$ \\
24 & Laren & 0,57 & 0,00 & $\mathbf{1 , 6 5}$ & $\mathbf{1 , 0 6}$ & $\mathbf{1 , 4 7}$ \\
25 & Solokuro & $\mathbf{1 , 3 0}$ & 0,00 & 0,26 & 0,74 & 0,94 \\
26 & Paciran & $\mathbf{1 , 0 9}$ & $\mathbf{9 , 6 5}$ & 0,00 & 0,85 & $\mathbf{1 , 0 7}$ \\
27 & Brondong & $\mathbf{1 , 0 2}$ & 0,00 & 0,00 & 0,85 & $\mathbf{1 , 1 6}$ \\
\hline & Sumber: Data Diolah $(2018)$ & & & &
\end{tabular}


Tabel sebaran LQ menunjukkan bahwa secara umum sumberdaya wilayah yang dimiliki oleh Kabupaten Lamongan masih memberikan dukungan terhadap sektor peternakan ruminansia yang ditandai dengan masih cukup besarnya populasi relatif di setiap wilayah. Populasi ternak ruminansia besar (sapi potong) terkonsentrasi di wilayah Lamongan bagian utara dan selatan, sementara kepemilikan ternak perah dan kerbau tidak terlampau banyak dan populasinya secara keseluruhan di Kabupaten Lamongan sangat sedikit sehingga nilai LQ untuk sektor ternak perah dan kerbau terlihat besar. Untuk ternak ruminansia kecil (domba dan kambing) memiliki sebaran populasi yang merata di setiap wilayah. Nilai indeks LQ bervariasi antar komoditas dan wilayah. Ternak ruminansia besar memiliki variasi indeks dengan rentang antara $0.00-19.13$, sementara $0.27-1.70$ untuk ternak ruminansia kecil.

Nilai dan variasi indeks merupakan dua indikator utama yang dapat digunakan untuk memperkirakan dan menentukan ternak yang dapat menjadi komoditas unggulan. Seperti yang terlihat di dalam tabel, rata-rata wilayah memiliki indeks yang lebih besar dari satu untuk ruminansia kecil, sementara indeks tersebut sangat bervariasi untuk ruminansia besar. Sejalan dengan itu, ruminansia besar memiliki rentang (variasi) indeks yang jauh lebih lebar dibandingkan dengan ruminansia kecil. Sebagaimana ternak yang berpotensi untuk menjadi komoditas unggulan dapat ditunjukkan oleh indeks yang lebih besar dari satu, maka ruminansia kecil tampaknya memiliki peluang yang cukup besar untuk memenuhi kriteria tersebut. Selanjutnya, kerapatan variasi indeks (index density Martin, 1996) pada ruminansia kecil merupakan indikator kesesuaian setiap wilayah terhadap pertumbuhan populasi ternak. Berdasarkan temuan tersebut, penentuan ruminansia kecil sebagai ternak unggulan (atau memiliki keunggulan komparatif) bagi Kabupaten Lamongan dapat dijustifikasi.

Pendugaan Potensi
Pengembangan Peternakan
Pendugaan potensi wilayah
pengembangan peternakan didasarkan pada
beberapa kriteria utama. Kriteria pertama
adalah keunggulan komparatif yang dimiliki
oleh suatu wilayah di dalam menghasilkan
pertumbuhan populasi ternak. Kriteria ini
diwakili oleh indeks LQ yang juga
menunjukkan komoditas ternak yang dapat

dijadikan prioritas pengembangan. Kriteria ke dua adalah daya dukung wilayah. Kriteria ini menunjukkan kemampuan suatu wilayah di dalam menghasilkan sumber pakan ternak. Kriteria ke tiga adalah sebaran rumahtangga pertanian yang memiliki lahan. Kriteria ini mewakili dimensi kelembagaan di dalam sektor peternakan; yang juga menunjukkan peluang pemanfaatan sumberdaya manusia di dalam proses pengembangan peternakan. Selain dari kriteria utama tersebut, kondisi infrastruktur yang diwakili oleh tingkat ketersediaan fasilitas pelayanan peternakan - dan rencana tataruang pemerintah daerah akan digunakan sebagai kriteria pendukung di dalam penentuan potensi wilayah.

Berdasarkan keseluruhan kriteria tersebut dan hasil pendugaan yang telah dilakukan maka terdapat beberapa wilayah kecamatan yang memiliki potensi cukup besar untuk dijadikan wilayah basis pengembangan peternakan di Kabupaten Lamongan. Potensi wilayah tersebut disajikan pada Tabel 2 berikut ini.

Tabel 2 menunjukkan keragaan ternak ruminansia di berbagai wilayah di Kabupaten Lamongan. Terdapat beberapa temuan penting dari hasil analisis yang dilakukan. Pertama, pertumbuhan populasi ternak ruminansia - sapi, kerbau, domba dan kambing - ternyata menunjukkan kecenderungan yang selalu meningkat antar waktu. Hal ini menunjukkan bahwa secara umum Lamongan memiliki lingkungan yang kondusif yang mendukung keberlangsungan usahaternak ruminansia. Kondisi ini juga dapat dijustifikasi dengan jumlah wilayah yang memiliki indeks $L Q$ di atas rata-rata; dimana dari 27 wilayah yang diamati hanya 6 wilayah yang memiliki indeks di bawah rata-rata, sementara lainnya menunjukkan indeks yang relatif cukup tinggi. Cukup banyaknya wilayah yang memiliki indeks relatif tinggi secara historis mengindikasikan cukup tingginya akseptabilitas wilayah - dari dimensi teknososioekonomi - terhadap perkembangan populasi ternak. 
Tabel2 Penentuan Wilayah Pengembangan Peternakan Ruminansia Besar dan Kecil di Kabupaten Lamongan

\begin{tabular}{|c|c|c|c|c|c|c|}
\hline No & Kecamatan & $\begin{array}{c}\text { Laju } \\
\text { pertu } \\
\text { mbuh } \\
\text { an } \\
\text { popul } \\
\text { asi }\end{array}$ & $\begin{array}{c}\text { Inde } \\
\text { ks } \\
\text { LQ }\end{array}$ & $\begin{array}{c}\text { Daya } \\
\text { Tampu } \\
\text { ng } \\
\text { Wilaya } \\
\text { h }\end{array}$ & $\begin{array}{l}\text { Indeks } \\
\text { Spesia } \\
\text { lisasi } \\
\text { rumah } \\
\text { tangga }\end{array}$ & $\begin{array}{c}\text { Status } \\
\text { Lahan } \\
\text { brdasar } \\
\text { Tata } \\
\text { ruang }\end{array}$ \\
\hline
\end{tabular}

\begin{tabular}{|c|c|c|c|c|c|c|}
\hline & & as! & & & & \\
\hline 1 & Sukorame & - & + & + & - & + \\
\hline 2 & Bluluk & - & + & + & + & + \\
\hline 3 & Ngimbang & + & + & + & + & + \\
\hline 4 & Sambeng & + & + & + & + & + \\
\hline 5 & Mantup & + & + & + & + & + \\
\hline 6 & Kb.bahu & + & - & - & - & + \\
\hline 7 & Sugio & - & - & - & - & + \\
\hline 8 & Kd.pring & + & + & - & - & - \\
\hline 9 & Modo & + & + & + & + & + \\
\hline 10 & Babat & + & - & - & + & - \\
\hline 11 & Pucuk & + & + & - & + & - \\
\hline 12 & Sukodadi & + & - & - & + & - \\
\hline 13 & Lamongan & + & - & - & + & - \\
\hline 14 & Tikung & + & + & + & + & + \\
\hline 15 & Sarirejo & - & - & + & - & + \\
\hline 16 & Deket & + & - & - & + & - \\
\hline 17 & Glagah & + & - & - & + & - \\
\hline 18 & Krb.nangun & - & - & - & + & - \\
\hline 19 & Turi & + & + & - & - & + \\
\hline 20 & Kalitengah & + & - & - & - & - \\
\hline 21 & Kr.geneng & + & - & - & + & - \\
\hline 22 & Sekaran & - & - & + & - & - \\
\hline 23 & Maduran & - & - & + & + & - \\
\hline 24 & Laren & - & - & + & + & - \\
\hline 25 & Solokuro & - & + & + & + & + \\
\hline 26 & Paciran & + & + & - & + & + \\
\hline 27 & Brondong & + & + & - & + & + \\
\hline
\end{tabular}

Keterangan: notasi (+) menunjukkan dukungan positif masing-masing aspek sumberdaya, sementara sebaliknya dengan notasi (-)

Sumber: Data diolah (2018)

Temuan ke dua berkaitan dengan kemampuan wilayah-wilayah di dalam menciptakan sumber pakan, yang dapat dilihat di dalam kolom daya tampung wilayah. Sebagaimana dengan indeks LQ, sebagian besar wilayah di Kabupaten Lamongan masih memiliki potensi sumberdaya yang dapat dimanfaatkan sebagai sumber pakan. Kondisi ini tidak terlepas dari masih cukup besarnya pangsa sektor pertanian di dalam struktur perekonomian wilayah. Selain itu, luas wilayah Kabupaten Lamongan juga merupakan salah satu faktor yang mendukung tingginya tingkat ketersediaan sumber pakan. Dalam temuan ini, terdapat dua fenomena yang cukup menarik. Terdapat beberapa wilayah yang memiliki indeks $L Q$ di atas rata-rata tetapi rendah tingkat ketersediaan pakan, serta begitu juga sebaliknya. Ngimbang dan Paciran menunjukkan indikasi seperti pada fenomena pertama. Khususnya Ngimbang, secara historis merupakan sentra sumberdaya yang dibutuhkan oleh sektor peternakan (resources pool); yang ditandai dengan indeks LQ yang cukup tinggi pada hampir seluruh komoditas ternak ruminansia (Tabel 3.2), sementara ternak ruminansia kecil - domba dan kambing - di Sambeng.

Kecenderungan semakin berkurangnya tingkat ketersediaan sumberdaya merupakan bukti empiris yang terdapat di kedua wilayah tersebut dengan berbagai penyebab. Ekspansi sektor sekunder - terutama industri diperkirakan menjadi penyebab utama berubahnya alokasi sumberdaya yang ada. Selain dari perubahan yang bersifat infrastruktural, eksternalitas yang ditimbulkan juga menyebabkan terjadinya perubahan pada struktur sosial-ekonomi masyarakat di wilayah tersebut. Sebaliknya dengan fenomena sebelumnya, beberapa wilayah menunjukkan tingkat surplus sumberdaya, beberapa di antaranya adalah Mantup dan Tikung. Rendahnya tingkat konsentrasi populasi ternak disertai dengan tingginya potensi pemanfaatan sumberdaya tampaknya dapat menjadi penjelasan sederhana untuk fenomena ini. Namun begitu, faktor kelembagaan tampaknya juga menjadi salah satu faktor penyebab tidak termanfaatkannya sumberdaya yang tersedia. Berdasarkan pengamatan yang dilakukan, terdapat kendala bagi peternak(pemelihara ternak) dalam mendapatkan akses terhadap sumber pakan. Kondisi ini dapat terjadi karena terdapat struktur penguasaan sumberdaya yang spesifik di wilayah tersebut (land tenure). Pada beberapa lokasi, tingginya tingkat penguasaan lahan per individu menyebabkan pemanfaatan lahan secara komunal menjadi sangat terbatas.

Rumahtangga pertanian - sebagai proksi dari sumberdaya manusia dan kelembagaan - ternyata masih merupakan basis ekonomi masyarakat Kabupaten Lamongan. Berdasarkan indeks spesialisasi rumahtangga, rumahtangga pertanian sangat umum terdapat di wilayah Lamongan bagian Selatan, Timur dan Barat Kabupaten Lamongan. Pada lokasi ini sebagian besar memiliki areal lahan pertanian yang cukup luas yang termasuk didalamnya adalah areal persawahan, perkebunan dan hutan. Sementara di bagian tengah dan utara, sebaran rumahtangga cenderung mendekati pusat infrastruktur, seperti wilayah kota dan industri serta jalan raya antar propinsi. Kondisi ini menunjukkan bahwa pengembangan ternak ruminansia dapat dengan secara efektif diarahkan kepada wilayah-wilayah Lamogan bagian selatan dan utara.

Wilayah pengembangan ternak ke arah selatan dan utara selaras dengan rencana tata ruang yang ditetapkan oleh pemerintah daerah setempat. Di dalam dokumennya, pemerintah menetapkan beberapa wilayah yang dijadikan sentra pengembangan sektor pertanian secara umum, sementara wilayah lainnya - meskipun masih memiliki sumberdaya yang potensial untuk dimanfaatkan oleh sektor peternakan - 
ditetapkan sebagai wilayah pengembangan industri dan jasa, seperti di Babat dan Paciran. Meskipun begitu, tentunya dapat dipahami oleh seluruh stakeholder di dalam sektor peternakan bahwa penetapan wilayah pengembangan ekonomi di suatu daerah biasanya lebih didasarkan kepada pemanfaatan land (lahan), bukan berdasarkan pemanfaatan space (keterkaitan ruang). Berdasarkan perspektif tersebut, Babat dan Paciran yang berada di sebelah Barat dan Utara Lamongan sebenarnya merupakan wilayah yang sangat ideal untuk menjadi sentra pengembangan ruminansia berdasarkan karakteristik ruangnya. Namun karena pengembangan infrastruktur dan pemanfaatan lahan Lamongan diarahkan ke Utara - yang merupakan pusat industri maritim, perdagangan dan pariwisata - maka kedua wilayah ini termasuk ke dalam wilayah industri dan jasa.

\section{KESIMPULAN}

Hasil penelitian ini menunjukan bahwa: (1) ternak ruminansia, khususnya ruminansia kecil, memiliki dukungan sumberdaya wilayah yang memadai untuk pengembangan peternakan di dalam jangka panjang sehingga dapat dijadikan komoditas unggulan bagi sektor peternakan di Kabupaten Lamongan; dan (2) Kecamatan Mantup, Tikung, Ngimbang, Sambeng, Modo, Solokuro dan Paciran merupakan wilayah kecamatan yang memiliki potensi sebagai basis pengembangan ternak unggulan tersebut.

Berdasarkan seluruh analisis yang dilakukan terhadap ketersediaan sumberdaya dan keterbatasan yang dimiliki oleh Kabupaten Lamongan, maka wilayah pengembangan ternak ruminansia dapat diarahkan di beberapa wilayah dan beberapa subsistem; subsistem budidaya dan pasca panen (pengolahan). Wilayah pengembangan ternak meliputi Kecamatan Mantup, Tikung, Ngimbang, Sambeng, Modo, Solokuro dan Paciran sebagai sentra pengembangan subsistem budidaya, sementara Sukorame, Deket dan Babat sebagai wilayah ekspansinya. Sementara subsistem pengolahan dapat diarahkan di Turi dan Paciran. Meskipun kedua wilayah ini tidak direncanakan untuk menjadi wilayah pengembangan sektor pertanian, tetapi subsistem pengolahan produk ternak tentunya masih dapat dilakukan. Upaya ini dapat dijustifikasi karena subsistem pengolahan tidak membutuhkan lahan sebagai basis produksinya, melainkan keterkaitan antar wilayah.

\section{DAFTAR PUSTAKA}

Badan Pusat Statistik. 2016. Angka Kabupaten Lamongan Propinsi Jawa Timur Hasil Pendaftaran Rumah Tangga. IX. Badan Pusat Statistik. Kabupaten Lamongan.

Badan Pusat Statistik. Berbagai terbitan, 20102016. Kabupaten Lamongan dalam Angka. Badan Pusat Statistik Kabupaten Lamongan.

Devendra, C. 2002. Crop Animal Systems in Asia: Future Perspectives. Agricultural Systems, Vol 1\&2, hal: 179-186.

Dinc, M. 2002. Regional and Local Economic Analysis Tools. Public Finance, Decentralization and Poverty Reduction Program. World Bank Institute. Washington.

Drescher, A. W., Jacobi, P. Dan Amend, J. 2000. Urban Agriculture, a Response to Crisis?. Urban Agriculture, Vol. 1, hal: 810

Ellis, F. dan Sumberg, J. 1998. Food Production, Urban Areas and Policy Responses. World Development, Vol 26, hal: 213-225.

Ethridge, D. 1995 Research Metodology in Applied Economics. IOWA State University Press. AMES.

Porter, M.E. 1998. Cluster and the New Economics Competition. Harvard Business Review, Vol. 76(6), hal: 77-90.

Sala-I-Martin, X. 1996. Regional Cohession: Evidence and Theories of Regional Growth and Convergence. European Economic Review, Vol 40, hal: 1325-52.

Steinfeld H., De Haan C. dan Blackbum H. 1997. Livestock-Environment Interactions: Issues and Options. European Comission DirectorateGeneral for Development. FAO Working Paper No. 41.

Upton, M. 2005. The Role of Livestock in Economic Development and Poverty Reduction. Pro-Poor Livestock Policy Initiative (PPLPI). FAO Working Paper No. 10. 